\title{
Analisis Pembingkaian Sosok SBY Dalam Buku "Membongkar Gurita Cikeas: Di Balik Skandal Bank Century" Karangan George Junus Aditjondro (Studi Analisis Teks Van Dijk).
}

\author{
Defiana Tities Riyandari \\ (defianatitiesriyandari39@gmail.com) \\ (Alumni Jurusan Ilmu Komunikasi Universitas Semarang)
}

\begin{abstract}
The book of "Membongkar Gurita Cikeas: Di Balik Skandal Bank Century" is George Junus Aditjondro's an activist expression media to critic SBY works on his leadership period. This book contain the social construction in every chapters, texts and languages that written. The framing/construction implementation on this book is using framing analyze. First step is do the Van Dijk text analyze using the elements of tematic, skematic, semantic, sintacist, stilistic and retorist. The text analyze on the book of "Membongkar Gurita Cikeas" find the constructions on SBY's frame.
\end{abstract}

Kata Kunci : SBY, Politik, Gurita cikeas

\section{Pendahuluan}

Setiap masa pemerintahan Indonesia melahirkan seorang aktivis, aktivis menciptakan suatu karya berupa sebuah buku sebagai bentuk ekspresi atas kinerja pemerintah. seperti buku Membongkar Gurita Cikeas: Di Balik Skandal Bank Century karangan George Junus Aditjondro. Dalam perjalanan beredarnya buku tersebut mengalami hambatan yang muncul dari pihak pemerintah. Buku tersebut menghilang setelah tiga hari beredar di pasaran, sebab menghilangny buku tersebut dikarenakan oleh kekawatiran pihak toko untuk mendisplay buku setelah adanya telepon gelap yang ditujukan ke pihak Gramedia grup. Dalam buku ini, penulis ingin membuka kesadaran masyarakat bahwa kasus korupsi saat ini terjadi bukanlah sederhana. Korupsi mucul karena terdapat suatu sistem yang sedemikian rupa dibentuk dan susah dibongkar. Wacana Bank Century membuka mata bahwa jabatan ganda dalam pemerintahan, parpol maupun bisnis sangat rentan dengan praktik KKN. Dimana beberapa orang dalam kabinet SBY juga mempunyai jabatan rangkap dan punya relasi dengan yayasan atau lembaga yang dikemudikan oleh keluarga SBY \& kroninya. Hal ini sangat kontradiktif dengan seruan lantang SBY "Katakan Tidak untuk Korupsi”. Untuk mengetahui lebih dalam dari buku tersebut, dilakukanlah analisis framing/pembingkaian atas sosok SBY yang digambarkan dalam buku Membongkar Gurita Cikeas : Di Balik Skandal Bank Century.

\section{Tinjauan Pustaka Buku Sebagai Media Cetak}

Cangara (2005: 128) Buku merupakan salah satu bentuk dari media cetak, adapun syarat-syarat yang telah mampu dipenuhi oleh buku dalam kajian sebagai media cetak yakni melalui proses percetakan, memiliki cover/sampul, 
mengangkat suatu isu (gender, politik, agama, budaya dan lainnya), adanya awalan dan akhiran pada cerita yang diangkat dan dipublikasikan. Buku sebagai media massa juga merupakan transmisi warisan sosial dari satu generasi ke generasi berikutnya, selain itu buku dapat dikatakan sebagai media massa karena mengandung karakteristik yang bersifat melembaga, media satu arah, meluas dan serempak, memakai peralatan teknis juga bersifat terbuka dimana pesan yang disampaikan dapat diterima siapa saja yang membacanya tanpa mengenal usia, jenis kelamin dan suku bangsa. Melalui sebuah buku, penulis atau penyusunnya bisa berbagi banyak hal seperti ilmu pengetahuan, pengalaman, bahkan imajinasi kepada pembacanya sehingga buku banyak digunakan untuk keperluan studi, pengetahuan, hobi atau media hiburan dengan kajian yang mendalam.

\section{Teori Konstruksi Media}

Bungin (2008: 15) Pembentukan konstruksi citra bangunan yang diinginkan oleh tahap konstruksi. Dimana bangunan konstruksi citra yang dibangun oleh media massa ini terbentuk dalam dua model: 1) model good news dan 2) model bad news. Model good news adalah sebuah konstruksi yang cenderung mengkonstruksi suatu pemberitaan sebagai pemberitaan yang baik. Pada model ini objek pemberitaan dikonstruksi sebagai sesuatu yang memiliki citra baik sehingga terkesan lebih baik dari sesungguhnya kebaikan yang ada pada objek itu sendiri. Sementara, pada model bad news adalah sebuah konstruksi yang cenderung mengkonstruksi kejelekan atau cenderung memberi citra buruk pada objek pemberitaan sehingga terkesan lebih jelek lebih buruk, lebih jahat dari sesungguhnya sifat jelek, buruk, dan jahat yang ada pada objek pemberitaan itu sendiri.

\section{Teori Framing}

Eriyanto (2002: 66) Framing adalah pendekatan untuk mengetahui bagaimana perspektif atau cara pandang yang digunakan oleh media ketika menyeleksi isu dan menulis berita. Framing terletak pada isu-isu yang diangkat oleh media. Van Dijk (Eriyanto, 2009: 224) framing terjadi melalui pembentukan konsensus dan pembenaran itulah yang dianggap sebagai kenyataannya. Teks yang ditulis oleh seorang jurnalis dipengaruhi oleh struktur sosial,kelompok kekuasaan, kognisi dan kesadaran. Teks untuk mengetahui bagaimana struktur teks yang dipakai untuk menegaskan suatu tema tertentu, Teori Framing bertujuan untuk mengidentifikasi skema penglihatan individu terhadap dunia.

\section{State Of The Art}

Teori dipakai sebagai informasi pembanding atau tambahan untuk melihat gejala yang diteliti secara lebih utuh. Karena tujuan utama penelitian kualitatif adalah untuk memahami gejala atau persoalan tidak dalam konteks mencari penyebab atau akibat dari sebuah persoalan lewat variabel yang ada melainkan untuk memahami gejala secara komprehensif, maka berbagai informasi mengenai persoalan yang diteliti wajib diperoleh. Informasi dimaksud termasuk dari hasil-hasil penelitian sebelumnya mengenai persoalan yang sama atau mirip.

Penelitian ini tentu berbeda dengan penelitian sebelumnya dengan menggunakan model framing yang umum dipakai oleh banyak peneliti, penelitian sebelumnya terpaku pada media berupa surat kabar dan media online sebagai lokasi penelitian dengan obyek pemberitaan kelompok maupun organisasi masyarakat saja. Sedangkan penelitian ini, 
menggunakan teknik analisis teks model Van Dijk dengan lokasi penelitian sebuah buku yang lebih detail dalam mengangkat isu dan mencoba mencari konstruksi eitra seorang tokoh (perorangan/bukan kelompok maupun anggota) nomor satu di Indonesia.

\section{Metodologi Penelitian \\ Lokasi Penelitian}

Obyek dari penelitian ini adalah buku Membongkar Gurita Cikeas : Skandal Bank Century karangan George Junus Aditjondro yang terbit pada tahun 2009, yang diterbitkan oleh Galang Press. Dimana buku tersebut menimbulkan kontroversi dengan pemerintah terutama SBY.

\section{Bentuk dan Strategi Penelitian}

Penelitian ini menggunakan penelitian kualitatif dengan menggunakan metode analisis framing untuk mengetahui bagaimana konstruksi SBY yang terbentuk dalam buku karya George Junus Aditjondro yang berjudul Membongkar Gurita Cikeas : Skandal Bank Century. Teknik yang digunakan adalah analisis teks.

\section{Data dan Sumber Data}

Data yang digunakan dalam penelitian ini adalah teks buku Membongkar Gurita Cikeas: Di Balik Skandal Bank Century. Yang dilengkapi dengan data-data yang diperoleh melalui kajian pustaka yang relevan sepaerti buku, surat kabar dan data dari internet.

\section{Teknik Cuplikan (Sampling)}

Pada penelitian kualitatif ini, sampel yang digunakan adalah sampel bertujuan (purposive sampling). Maksud dari sampling ini adalah untuk menjaring sebanyak mungkin informasi dari pelbagai macam sumber dan bangunannya (constructions). Pembingkaian sosok SBY diperoleh dengan kriteria sampling sebagai berikut :

Bab tentang SBY (buku Membongkar Gurita Cikeas: Di Balik Skandal Bank Century)

\section{Teknik Pengumpulan Data}

Menyesuaikan dengan bentuk penelitian kualitatif dan jenis sumber data yang dimanfaatkan, maka teknik pengumpulan data yang digunakan dalam penelitian ini adalah buku. Yang bertujuan untuk mengetahui penekanan makna pada teks yang dituangkan penulis. Dilakukan pula observasi berperan penuh dan pencatatan serta mengkritisi data-data tertulis sebagai pendukung data di lapangan.

\section{Validitas Data}

Teknik pemeriksaan diperlukan untuk menetapkan keabsahan (trustworthiness) data. Ada empat kriteria yang digunakan, yaitu derajat kepercayaan (credibility), keteralihan (transferability), kebergantungan (dependability), dan kepastian (confirmability) (Moleong, 2012: 324).

\section{Teknik Analisis Data}

Penelitian ini menggunakan teknis analisis data yang dipakai adalah teknis analisis framing dengan mengkonstruksi fakta yang menggunakan model analisis framing Teun A. Van Dijk dengan menggunakan metode analisis teks. Karena teks merupakan hasil dari suatu praktik produksi yang harus juga diamati. Dari teks kita dapat mengetahui sejauh mana frame seorang sosok SBY dikonstruksikan dalam buku karangan George Junus yang berjudul Membongkar Gurita Cikeas. Langkah yang dilakukan adalah menganalisis struktur teks yang terdapat enam elemen yaitu tematik yang terdiri dari topik, skematik yang terdiri dari skema, 
semantik terdiri dari latar, detil, maksud, praanggapan dan nominalisasi, sintakis yang meliputi betuk kalimat, koherensi dan kata ganti, stilistik meliputi leksikon sedangkan untuk retoris terdiri dari grafis, metafora dan ekspresi (Eriyanto, 2009: 227-25)

\section{Tabel Skema Analisis Teks Van Dijk}

\begin{tabular}{|c|c|c|}
\hline $\begin{array}{c}\text { STRUKTUR } \\
\text { WACANA }\end{array}$ & $\begin{array}{c}\text { HAL YANG } \\
\text { DIAMATI }\end{array}$ & ELEMEN \\
\hline Struktur Makro & \begin{tabular}{l}
\multicolumn{2}{c}{ Tematik } \\
Tema/topik yang \\
dikedepankan dalam \\
suatu berita
\end{tabular} & Topik \\
\hline Superstruktur & \begin{tabular}{l}
\multicolumn{2}{c}{ Skematik } \\
Bagaimana bagian \\
dan urutan berita \\
diskemakan dalam \\
teks berita utuh
\end{tabular} & Skema \\
\hline Struktur Mikro & 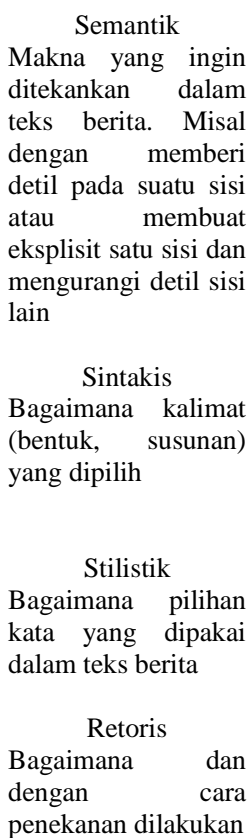 & $\begin{array}{l}\text { Latar, detil, } \\
\text { maksud, } \\
\text { praanggapan, } \\
\text { nominalisasi } \\
\text { Bentuk kalimat, } \\
\text { koherensi, kata } \\
\text { ganti } \\
\text { Leksikon } \\
\\
\text { Grafis, } \\
\text { metafora, } \\
\text { ekspresi }\end{array}$ \\
\hline
\end{tabular}

\section{Hasil dan Pembahasan}

\section{Analisis Buku Membongkar Gurita Cikeas: Di Balik Skandal Bank Century}

Analisis teks sesuai dengan model yang digunakan, dan diamati secara rinci dan detil dalam setiap bab dari buku Membongkar Gurita Cikeas. Hasil analisis teks yang dilakukan dalam tiap babnya yakni:

a. Bab 1 dengan judul Membongkar Gurita Cikeas: Di Balik Skandal Bank Century dengan elemen yang ditemukan adalah 1) Tematik, mengangkat tema tentang pengalihan isu dari skandal Bank Century; 2) Skematik, alur yang digunakan pada awal paragraf adalah kutipan pidato SBY pada tanggal 23 November 2013 yang selanjutnya diperjelas dengan tindakan-tindakan pengalihan isu yang dilakukan; 3) Semantik, makna yang ditekankan pada bab ini yaitu konflik antara KPK versus Mabes Polri; 4) Sintakis, kalimat yang tersusun merupakan uraian hal-hal umum yang kemudian semakin mengerucut dan fokus; 5) Stilistik, pemilihan kata yang digunakan pada bab ini 'tabir asap' secara ideologis menyatakan pengalihan isu terhadap konflik yang ada; 6)Retoris, bagian yang dianggap penting menggunakan kata kiasan seperti 'kotak pandora' yang mempunyai arti sesuatu hal yang tampak indah namun didalamnya penuh dengan kejahatan, keburukan dan juga kata 'cicak melawan buaya' yang ditulis dengan grafis penulisan dicetak miring.

b. Bab 2 dengan judul Bantuan Grup Sampoerna Untuk Harian Jurnas, elemen yang ditemukan adalah 1) Tematik, mengangkat tema tentan hubungan sampoerna grup dengan lingkungan SBY dan skandal Bank Century; 2) Skemantik, alur diawali dengan rangkaian silsilah keluarga sampoerna hingga keterikatannya dengan keluarga SBY; 3) Semantik, latar yang dipilih tentang relevansi informasi yang hendak ditampilkan penulis dengan keluarga Cikeas, kemudian silsilah keluarga 
sampoerna dijadikan latar belakang pada bab ini; 4) Sintakis, kata ganti yang digunakan 'grup sampoerna' yang menjelaskan semua keluarga \& bisnis keluarga sampoerna yang mempunyai hubungan dengan peristiwa yang diuraikan; 5) Stilistik, pemilihan kata 'disuntikan' yang memberikan makna sumbangan/pemberian dana; 6) Retoris, kata kiasan yang digunakan 'keluarga Cikeas' yang mempunyai arti seluruh keluarga besar SBY.

c. Bab 3 yang berjudul Pemanfaatan PSO LKBN Antara Untuk Bravo Media Center, elemen yang ditemukan adalah 1) Tematik, tema yang diangkat tentang pengalihan dana publik untuk biaya kampanye SBY oleh BUMN; 2) Skemantik, alur diawali dengan pernyataan kemudian dilanjutkan dengan fakta-fakta yang menjadi penjelas secara rinci dan pada paragraph akhir menerangkan sebuah kesimpulan sederhana yang menjelaskan maksud peristiwa; 3) Semantik, pemilihan kata 'perangkapan jabatan' untuk menujukkan makna bahwa terdapat jabatan ganda yang menjadi tim sukses kampanye SBY-Boediono dan detil dalam bentuk pertanyaanpertanyaan dugaan untuk membuka pemikiran kritis yang mempengaruhi citra BUMN dalam peranannya kepada kesuksesan kampanye SBYBoediono; 4) Sintakis, penggunaan koherensi akibat dari suatu fakta dan penggunaan kata ganti 'jejaring militan' sebagai pengganti dari kelompok agresif; 5) Stilistik, pemilihan kata didominasi dengan kata-kata ilmiah tetapi tidak keluar dari makna yang ingin disampaikan misalnya korporasi; 6) Retoris, penggunaan kata kiasan 'dana siluman' yang ditulis dengan menggunakan tanda petik untuk mempertegas suatu kalimat.

d. Bab 4 yang berjudul Yayasan Yang Berafiliasi Dengan SBY dan Ani Yudhoyono, elemen yang ditemukan adalah 1) Tematik, yayasan -yayasan yang mempunyai hubungan dengan SBY dan keluarga termasuk pejabatpejabat/kerabat SBY; 2) Skematik, teks ditulis dalam bentuk cerita tentang jalannya suatu peristiwa dan komentar yang ditampilkan dalam teks oleh penulis; 3) Semantik, latar diawali dengan informasi bahwa ada banyak yayasan yang mempunyai keterikatan dengan kampanye Partai Demokrat yang dijelaskan secara eksplisit; 4) Sintakis, terdapat koherensi pembanding dan kalimat pengingkaran. Bentuk kalimat yang digunakan deduktif dengan adanya kata ganti 'ketiga yayasan' sebagai representasi dari yayasan yang berafiliasi dengan keluarga SBY yaitu Yayasan Mutu Manikam Nusantara, Yayasan Batik Indonesia, Yayasan Sulam Indonesia; 5) Stilistik, pemilihan kata 'kediktatoran' yang menunjukkan fakta dan memberikan penegasan makna dari teks; 6) Retoris, grafis yang ditunjukkan pada bab ini berupa foto-foto keluarga dan kerabat SBY beserta lampiranlampiran. Dan juga terdapat perumpamaan kata 'sang markus' yang ditujukkan kepada Ayin yang berarti sang makelar kasus.

e. Bab 5 yang berjudul PelanggaranPelanggaran UU Pemilu Oleh CalegCaleg Partai Demokrat, elemenelemen yang ditemukan adalah 1) Tematik, potensi pelanggaran UU Pemilu karena perangkapan jabatan Kabinet Indonesia Bersatu (KIB) jilid 2 dengan pengurusan yayasan; 2) Skematik, skema menggunakan 
elemen cerita dengan cara deduktif; 3) Semantik, latar yang digunakan menguraikan tindakan para caleg yang melakukan pelanggaran UU Pemilu; 4) Sintakis, penggunaan kalimat aktif dengan koherensi pembeda antar caleg dalam melakukan pelanggaran UU Pemilu; 5) Stilistik, pemilihan kata yang digunakan 'mantan kombatan' yang ditujukkan untuk caleg yang berada di Aceh; 6) Retoris, grafis yang digunakan tanda petik pada kata 'politik uang' untuk mempertegas makna teks.

\section{Pembahasan Hasil Analisis Buku 'Membongkar Gurita Cikeas: Di Balik Skandal Bank Century'}

Analisis framing diperoleh dari pengamatan teks yang menghasilkan konstruksi sosok SBY pada buku Membongkar Gurita Cikeas. Hasil konstruksi tersebut yang pertama adalah SBY sosok propaganda yang ditemukan pada bab 1 dengan tujuan untuk mengembalikan krisis kepercayaan publik. Yang kedua SBY sosok pelaku korupsi, kolusi dan Nepotisme (KKN) ditemukan pada bab 2, 3, 4 juga 5. Hasil ini merupakan bentuk eksternalisasi dari penulis seperti yang diungkapkan Berger dalam teori konstruksi sosial media. Dimana terdapat dua model hasil konstruksi pembentukan citra yaitu good news dan bad news, namun yang ditunjukkan pada buku ini merupakan konstruksi pembentukan citra dalam bentuk bad news. Dari ciri-ciri yang ditemukan, pembingkaian sosok SBY adalah SBY merupakan sosok kepala pemerintah (presiden) yang tidak amanah, karena tidak dapat menjalankan tugas dengan baik.

\section{Kesimpulan}

Dari penelitian yang telah dilakukan, dapat ditarik kesimpulan bahwa buku
Membongkar Gurita Cikeas: Di Balik Skandal Bank Century membingkai sosok SBY sebagai kepala pemerintah (presiden) yang tidak amanah. Dengan ciri-ciri yang diuraikan pada bab 1 menggambarkan sosok SBY telah melakukan propaganda untuk mengembalikan kepercayaan publik dan pengalihan isu-isu yang tertuju kepada kasus Bank Century. Sedangkan pada bab 2, 3, 4 dan 5 menggambarkan sosok SBY sebagai pelaku tindakan korupsi, kolusi dan nepotisme (KKN).

Penelitian ini sudah merupakan studi framing. Penelitian ini menemukan konstruksi media atas sosok SBY yang merupakan tujuan dari analisis framing. Dan memperkuat teori framing bahwa realitas merupakan hasil dari konstruksi media, dan bagaimana media mengarahkan khalayak untuk opini publik tertentu. Sehingga opini yang terbentuk oleh khalayak mempengaruhi sikap khalayak atas suatu peristiwa/isu yang diangkat oleh media tersebut. Hasil konstruksi tersebut diperoleh dari analisis teks model Van Dijk yang mempunyai tiga unsur yaitu struktur makro, superstruktur dan struktur mikro sebuah wacana. Dimana masing-masing struktur mengandung elemen-elemen seperti tematik, skematik, semantik, sintakis, stilistik, retoris. Implikasi sosial lainnya menunjukkan bahwa pembingkaian tentang sosok SBY pada buku Membongkar Gurita Cikeas menjadi tolak ukur untuk menentukan pilihan seorang pemimpin pada periode mendatang

Saran yang dapat dikemukakan adalah segala bentuk aspirasi rakyat dengan cara etis sebaiknya tidak terdapat pelanggaran, sebagai wujud kritikan atas kinerja pemerintah supaya lebih baik. Penelitian ini diharapkan dapat memacu munculnya penelitian sejenis dengan permasalahan yang lebih kompleks 
sehingga dapat mendukung pengembangan ilmu pengetahuan dan wawasan masyarakat dalam bidang komunikasi.

\section{Daftar Pustaka}

Alex Sobur. 2006. Analisis Teks Media (Suatu Pengantar Untuk Analisis Wacana, Analisis Semiotik Dan Analisis Framing). Bandung : PT. Remaja Rosdakarya.

Bungin, Burhan. 2008. Konstruksi Sosial Media Massa. Jakarta: Prenata Media.

Eriyanto. 2001. Analisis Wacana : Pengantar Analisis Teks Media. Yogyakarta : PT. LKiS Pelangi Aksara.

2002. Analisis Framing :

Konstruksi, Ideologi, dan Politik Media. Yogyakarta : PT. LKiS Pelangi Aksara.

2005. Analisis Framing :

Konstruksi, Ideologi, dan Politik
Media. Yogyakarta : PT. LKiS Pelangi Aksara. . 2009. Analisis Wacana : Pengantar Analisis Teks Media. Yogyakarta : PT. LKiS Pelangi Aksara.

H. Hafied Cangara. 2005. Pengantar Ilmu Komunikasi. Jakarta : PT. Raja Grafindo Persada.

Lexy J. Moleong. 2005. Metodologi Penelitian Kualitatif. Bandung : Remaja Rosda Karya.

http://www.bit.lipi.go.id/masyarakatliterasi/index.php/dari-papyrus-kepaperless/572 diunduh tanggal 10 Juni 2012.

Sikap ELSAM perihal Pembredelan Buku, http://indonesiabuku.com/?p=3210 , diunduh tanggal 5 Mei 2013. 